\title{
Congenital Myasthenic Syndrome in the Dog Breed Gammel Dansk Hønsehund: Clinical, Electro- physiological, Pharmacological and Immunological Comparison with Acquired Myasthenia gravis
}

\author{
By Annette Flagstad, Werner Trojaborg and Steen Gammeltoft \\ Department of Small Animal Diseases and Clinical Practice, \\ Royal Veterınary and Agricultural Unıversity, Copenhagen, \\ Laboratory of Clinical Neurophysiology, Rigshospitalet, Unıversity of Copenhagen, and \\ Department of Clınical Chemistry, Bıspebjerg Hospital, Copenhagen, Denmark.
}

\begin{abstract}
Flagstad, A, W. Trojaborg and S. Gammeltoft: Congenital myastenic syndrome in the dog breed Gammel Dansk Hønsehund: Clinical, electrophysiological, pharmacological and immunological cmparison with acquired myasthenia gravis. Acta vet. scand. 1989, 30, 89-102. - The effect of anticholinesterase drugs on the clinical and electrophysiological features in a canine congenital myasthenic syndrome is compared with findings in acquired myasthenia gravis in dogs. Anticholinesterase treatment had no effect on muscle weakness or electrophysiological parameters in the congenital myasthenic syndrome in contrast to its effect on clinical signs and electrophysiological parameters in acquired myasthenia gravis. The lack of effect of anticholinesterase in congenital myasthenia suggests a presynaptic defect as the aetıological factor. No antıbodies to acetylcholine receptors were found in the Danish dog breed Gammel Dansk Hønsehund with the myasthenic syndrome. This classifies the disease in the group of canıne and human congenital myasthenic diseases.
\end{abstract}

myasthenic syndrome; canine myasthenıa gravis; neuromuscular transmission defect.

\section{Introduction}

Attacks of canine fatigability caused by a neuromuscular transmission defect occur in a congenital and in an acquired form. The acquired type is an autoimmune disease with detectable circulating antibodies directed towards acetylcholine receptors at the neuromuscular junction where immune complexes have also been found (Lennon et al 1978, Pflugfelder et al. 1980). In addition, there is a reduced number of postsynaptic acetylcholine receptors (Lennon et al. 1978). Acquired myasthenia gravis (MG) has been reported in dogs aged 2-5 years especially in large breeds (Lennon et al.
1978, Palmer \& Barker 1974, Kelly 1981). It is often associated with megaoesophagus (Lennon et al. 1978), and occasionally with thymoma (Hall et al. 1972, Bellah et al 1983, Poffenbarger et al. 1984).

In congenital MG there is a decreased number of acetylcholine receptors at the postsynaptic membrane, but no circulating antibodies against them (Lennon et al. 1978, Miller et al 1983). The disease has been described in breeds of Springer Spaniels (Lennon et al 1978, Johnson et al. 1975), Jack Russel Terriers (Lennon et al. 1978, Palmer \& Barker 1974, Palmer \& Goodyear 1978), and Smooth Fox Terriers (Miller et 
al. 1983, Jenkins et al. 1976). The symptoms usually set in at the age of 6-9 weeks. Megaesophagus has been demonstrated in the Smooth Fox Terrier only (Miller et al. 1983). The disease is inherited in an autosomal recessive manner in the Jack Russel Terrier (Wallace \& Palmer 1984) and the Smooth Fox Terrier (Miller et al. 1984). In the Jack Russel Terrier, copulation has been impossible due to the severity of the disease, and artificial insemination has been unsuccessful (Wallace \& Palmer 1984). It has not been possible to raise an affected Smooth Fox Terrier to sexual maturity, so that in this breed the disease is considered lethal (Miller et al. 1984).

Acquired and congenital MG is characterized clinically by intermittent attacks of muscle fatigue, physiologically by a decrement of the electrical muscle activity during repetitive nerve stimulation (Miller et al. 1983, Zacks et al. 1966, Lennon et al. 1981), and pharmacologically by the response to anticholinesterase drugs (Miller et al. 1983, Palmer 1980).

A new type of neuromuscular disorder has recently been described in dogs of the breed Gammel Dansk Hønsehund (Flagstad 1982, Trojaborg \& Flagstad 1982). It is of autosomal recessive inheritance and is characterized by reduced tolerance to exercise, not reversed by anticholinesterase drugs. The physiological effects consist of an initial increment of muscle activity during $5 \mathrm{~min}$ of $15 \mathrm{~Hz}$ repetitive nerve stimulation, followed by fatigue, and then a decrement at $3 \mathrm{~Hz}$ stimulation (Trojaborg \& Flagstad 1982). The initial potential amplitude increment is similar to, although less pronounced than that found in the Lambert-Eaton syndrome in man which is due to a presynaptic defect of acetylcholine quanta release (Otsuka \& Endo 1960, Karmenskaya et al. 1975). Guanidine hydrochloride improves muscu- lar function in the Lambert-Eaton syndrome as well as in the Gammel Dansk Hønsehund (Flagstad et al. 1986).

In the present report we describe the pharmacological effect of anticholinesterase treatment of the congenital myasthenic syndrome in Gammel Dansk Hønsehund compared with the findings in acquired canine MG. Furthermore, measurements of antibodies to acetylcholine receptors were used to discriminate between congenital and acquired MG.

\section{Materials and methods}

Dogs with a congenital myasthenic syndrome

Fourteen dogs of the breed Gammel Dansk Hønsehund, 6 males and 8 females referred to the Clinic during 1980-1985 because of recurrent episodes of muscle fatigue after exercise, were studied. Seven dogs were 12 weeks -6 months old, and 7 were 1-2 years. The first signs had been noticed at the age of 12-16 weeks.

Experimental dogs were selected from a colony of Gammel Dansk Hønsehund offspring, bred from 3 affected dogs. The development of the clinical signs was followed in 4 litters born at the Clinic, and the effect of anticholinesterase drugs was studied in 10 dogs 12-16 week-old as well as in 15 adult dogs from the colony.

\section{Acquired myasthenia gravis}

Five dogs of different breeds aged 8 months - 5 years were referred to the Clinic where acquired MG was diagnosed. Their data are listed in Table 1.

\section{Clinical and laboratory examination}

All dogs were examined clinically, including neurological tests and response to exercise. Barium sulfate studies were performed to 
Table 1. Clinical signs and response to anticholinesterase.

\begin{tabular}{|c|c|c|c|c|c|c|c|c|}
\hline \multirow[b]{3}{*}{ 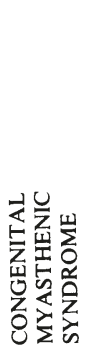 } & \multirow{3}{*}{$\begin{array}{l}\text { Breed of dog } \\
25 \text { dogs of } \\
\text { the breed } \\
\text { Gammel Dansk } \\
\text { Hønsehund }\end{array}$} & \multirow[b]{2}{*}{$\begin{array}{l}\text { Age at } \\
\text { onset } \\
\text { of signs }\end{array}$} & \multirow[b]{2}{*}{$\begin{array}{l}\text { Episodic } \\
\text { attacks of } \\
\text { weakness }\end{array}$} & \multirow[b]{2}{*}{$\begin{array}{l}\text { General } \\
\text { weakness }\end{array}$} & \multirow[b]{2}{*}{$\begin{array}{l}\text { Megaoeso- } \\
\text { phagus }\end{array}$} & \multicolumn{2}{|c|}{ Anticholinesterase response } & \multirow[b]{2}{*}{ Course } \\
\hline & & & & & & $\begin{array}{l}\text { Prevention } \\
\text { of attacks } \\
\text { and effect } \\
\text { on general } \\
\text { weakness }\end{array}$ & $\begin{array}{l}\text { Prevention } \\
\text { of electro- } \\
\text { physiological } \\
\text { myasthenıc } \\
\text { decrement }\end{array}$ & \\
\hline & & $\begin{array}{l}\text { about } \\
12 \text { weeks }\end{array}$ & + & Neg & Neg & Neg & Neg & $\begin{array}{l}\text { No progression } \\
\text { of symptoms }\end{array}$ \\
\hline \multirow{5}{*}{ 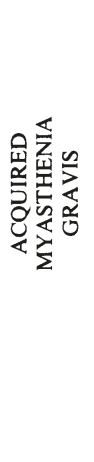 } & Boxer & 5 years & $\begin{array}{l}\text { Not exer- } \\
\text { cised due } \\
\text { to osteo- } \\
\text { arthritis }\end{array}$ & $\mathrm{Neg}$ & + & + & + & $\begin{array}{l}\text { Died of aspira- } \\
\text { tion pneumonia }\end{array}$ \\
\hline & $\begin{array}{l}\text { Labrador } \\
\text { mongrel }\end{array}$ & 1 year & + & neg & + & + & + & \multirow{3}{*}{$\begin{array}{l}\text { Euthanized due } \\
\text { to hip dysplasia } \\
\text { dead, thymus tu- } \\
\text { mour, aspiration } \\
\text { pneumonia } \\
\text { Recovered }\end{array}$} \\
\hline & $\begin{array}{l}\text { German Shep- } \\
\text { herd mongrel }\end{array}$ & 5 years & + & + & + & + & + & \\
\hline & $\begin{array}{l}\text { German } \\
\text { Shepherd }\end{array}$ & 4 years & + & Neg & Neg & + & + & \\
\hline & Shih Tzu & 8 months & + & + & Neg & + & ND & $\begin{array}{l}\text { Recovered after } \\
\text { treatment for } \\
\text { two months }\end{array}$ \\
\hline
\end{tabular}

$\mathrm{Neg}=$ Negatıve ND $=$ not determined

evaluate the diameter of the oesophagus. Blood samples were evaluated for $\mathrm{HB}, \mathrm{RBC}$, $\mathrm{WBC}, \mathrm{BUN}$, calcium, magnesium, sodium, potassium, chloride and phosphorus, creatine kinase $(\mathrm{CK})$, aspartate-aminotransferase (ASAT), alanine aminotransferase (ALAT), lactate and glucose. Blood samples were drawn at rest and during attacks of muscle weakness. Lactate and CK were reexamined on the day after an attack. The serum thyroxine and cortisol were determined. Electrocardiograms were recorded at rest and during attacks.

\section{Electrophysiological examınation}

This was performed under anaesthesia induced with intravenous thiopentane and maintained by halothane in nitrous oxide and oxygen. To reduce muscle movement the stimulated leg was fixed to a frame attached to the examination table. The sciatic nerve was stimulated at the sciatic notch by needle electrodes, and muscle action potentials were recorded from the biceps muscle by a subcutaneous needle electrode placed in the endplate zone and a referrent needle electrode subcutaneously at the stifle (Fig. 1a). The stimulus strength was 12-15 mA, i. e. 15-20 times above threshold level. Muscle action potentials were recorded on paper after single and repetitive stimuli (Neuromatic 2000, DISA-DANTEC). Single stimuli were given to determine the amplitude of the negative phase of the muscle action potential. The neuromuscular transmission was examined at various rates and duration of repetitive stimulation as follows: 


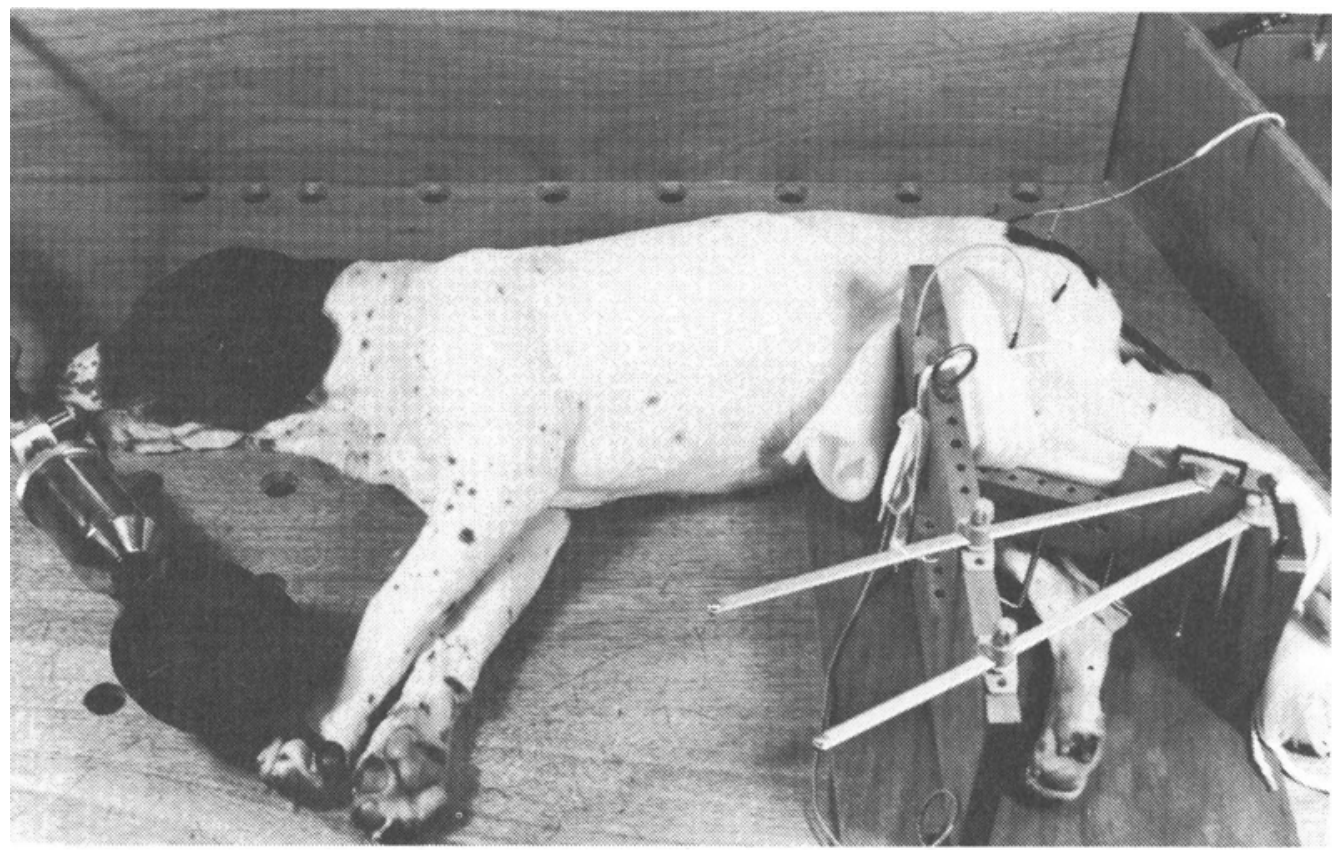

Figure 1 a. Gammel Dansk Hønsehund. One hind leg is fixed to a frame. The frame is adjusted according to the size of the dog. The sciatic nerve is stımulated with needle electrodes, and muscle action potentials are recorded from the biceps femoris muscle.

1) $3 \mathrm{~Hz}$ for $3 \mathrm{~s}$ repeated $5-10$ times at intervals of 30 to $120 \mathrm{~s}$,

2) trains of $50 \mathrm{~Hz}$ for $20 \mathrm{~s}$ followed by single stimuli at 2,5 and $10 \mathrm{~s}$ and after $30 \mathrm{~s}$ by $3 \mathrm{~Hz}$ for $3 \mathrm{~s}$,

3) $15 \mathrm{~Hz}$ for $5 \mathrm{~min}$ followed by single stimuli after 2,5 and $10 \mathrm{~s}$. The trains of $3 \mathrm{~Hz} / 3 \mathrm{~s}$ were given after $30 \mathrm{~s}$ and each minute until the action potential returned to its initial level. The $15 \mathrm{~Hz}$ stimulation was repeated 2 or 3 times at $2-5$ min interval.

Changes in muscle potential amplitude were expressed in \% of the amplitude of the first response.

\section{Administratıon of anticholınesterase}

To study the effect on muscle fatigue, 10 adult experimental dogs and 10 dogs 12-14 week-old were given edrophonium* 1-2 mg per $10 \mathrm{~kg}$ body weight or neostigmine** 0.5 $\mathrm{mg}$ per $10 \mathrm{~kg}$ body weight i. v. Furthermore, 5 of the adult experimental dogs were treated orally with neostigmine*** $5 \mathrm{mg}$ per $10 \mathrm{~kg}$ body weight 3 times daily for 5 weeks $(15 \mathrm{mg} / 10 \mathrm{~kg} /$ day $)$.

The tolerance to exercise after treatment with anticholinesterases was tested by running in an ergometer. Before treatment the tolerance to exercise was examined in four dogs during a two-weeks period. Three dogs received neostigmine $0.5 \mathrm{mg}$ per $10 \mathrm{~kg}$ body weight i. v. $5 \mathrm{~min}$ before running in the ergometer. One dog was treated orally with neo-

* Tensilon Roche 10 mg edrophonıum chloride $/ \mathrm{ml}$.

** Neostigmine solution $0.5 \mathrm{mg} / \mathrm{ml}$.

*** Neostigmine tablets $15 \mathrm{mg}$. 
stigmine $7.5 \mathrm{mg}$ per $10 \mathrm{~kg}$ body weight twice a day for 3 weeks. The tests were repeated 2-3 times in each dog.

Neostigmine $(0.5 \mathrm{mg}, 1.0 \mathrm{mg}$, or $2.5 \mathrm{mg} / 10$ $\mathrm{kg}$ body weight) was given intravenously during the electrophysiologic tests to 11 dogs, and the effect of edrophonium was tested by injection of 1-2 mg per $10 \mathrm{~kg}$ body weight in 3 adult and 5 14-week-old dogs.

In dogs with acquired MG the effect of anticholinesterase was evaluated by repetitive nerve stimulation after intravenous injection of 0.1 to $0.5 \mathrm{mg}$ neostigmine per 10 $\mathrm{kg}$ body weight. Treatment was then started, and the clinical response was recorded after intravenous administration of neostigmine $0.5 \mathrm{mg}$ per $10 \mathrm{~kg}$ body weight followed by an oral dose of $7.5 \mathrm{mg}$ per $10 \mathrm{~kg}$ body weight twice a day $(15 \mathrm{mg} / 10 \mathrm{~kg} /$ day $)$.

\section{Determinatıon of antibodies to acetylcholıne receptors}

The content of antibodies to acetylcholine receptors in canine plasma was determined as previously described in detail for assay of antibodies in human plasma (Nielsen et al 1985). Acetylcholine receptors were prepared from normal canine skeletal muscle by homogenization and dissolution in Triton $\mathrm{X}-100$. After labelling with ${ }^{125}$ I-bungarotoxın, canıne acetylcholine receptors were incubated for $2 \mathrm{~h}$ at $20^{\circ} \mathrm{C}$ with myasthenic canine plasma, followed by addition of rabbit antibody to canine IgG overnight at $4^{\circ} \mathrm{C}$. The precipitated complexes of ${ }^{125}$ I-bungarotoxin-labelled acetylcholine receptors and canine IgG were counted and corrected for non-specifically precipitated ${ }^{125} \mathrm{I}$-activity determined by normal canine plasma. The results were considered as positive when the amount of ${ }^{125}$ I-labelled acetylcholine receptors precipitated by myasthenic canine plasma was higher than that precipitated by normal canine plasma.
The myasthenic canine plasma samples were also assayed by incubation with a preparation of acetylcholine receptors from normal human skeletal muscle followed by precipitation with rabbit antibody to human IgG.

\section{Results}

\section{Clinıcal findings}

The puppies showed no clinical signs of fatigue before the age of 12 weeks. They gained weight and were as healthy as normal puppies.

The first attack of fatigue after exercise started at the age of 12 weeks (Fig. $1 \mathrm{~b}$ and 1c), the dogs taking shorter strides, walking with flexed forelegs and hindlegs, exhibiting head drooping and sometimes falling. After a few minutes of rest they were able to walk and run again for variable periods of time before the signs reappeared. During the attacks muscle tone and tendon reflexes were normal; there was no change in facial appearance, and barking intensity was unaffected. There was no swallowing defect or evidence of megaoesophagus. The disorder did not progress, and the dogs were in good health throughout the observation period. At the present time 2 dogs have been followed at the Clinic for 6 years. Mating has been possible, pregnancy and delivery have been normal. Bitches even seemed to improve during pregnancy, having fewer attacks of muscle weakness.

Five dogs with acquired MG suffered from exercise-induced fatigue similar to that seen in the Gammel Dansk Hønsehund breed, but also showed signs of generalized weakness. Regurgitation due to megaoesophagus, anorexia, eating and drinking difficulties, increased salivation, and decreased bark intensivity were observed in 3 of the dogs (Table 1). In 1 dog a thymoma was found at post mortem examination. 


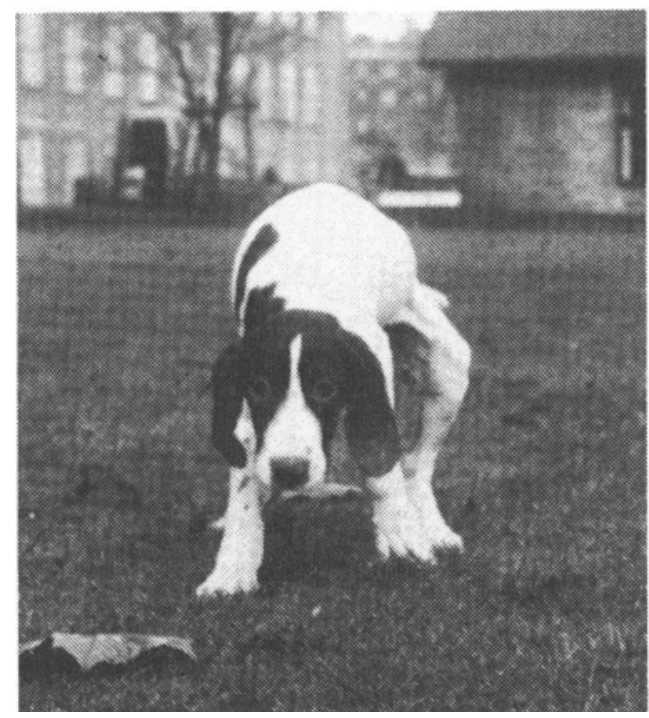

Figure 1b. A 13-week old Gammel Dansk Hønsehund with an attack of muscular weakness. The dog has stopped running and takes only short strides.

\section{Laboratory findings}

No abnormalities were found in haemograms, electrolytes, muscle enzymes, lactate, glucose, thyroxine or cortisol during attacks or at rest. Electrocardiograms were normal.

\section{Electrophysiologıcal findings}

Three $\mathrm{Hz}$ stimulations for $3 \mathrm{~s}$ repeated 5-10 times did not reveal changes of the muscle action potential in dogs with the congenital myasthenic syndrome. Stimulation with 50 $\mathrm{Hz}$ for $20 \mathrm{~s}$ caused an $80 \%$ amplitude decrement. The action potential recovered immediately when single stimuli were given 2,5 and $10 \mathrm{~s}$ after tetanic stimulation, and there was no decrement on $3 \mathrm{~Hz}$ stimulation for $3 \mathrm{~s}$.

At $15 \mathrm{~Hz}$ stimulation for $5 \mathrm{~min}$ there was a steady amplitude increment during the first minute, in some dogs up to $70 \%$, followed by a gradual decrement of $40-85 \%$. In some

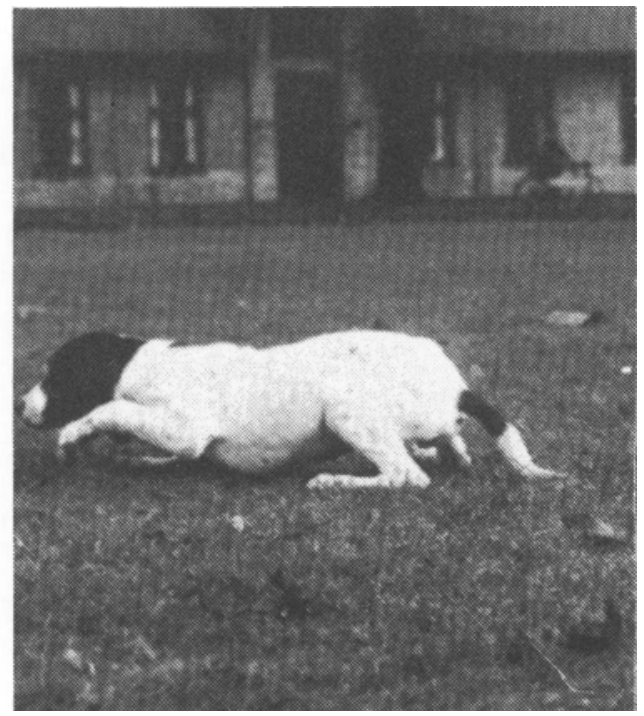

Figure 1c. Same dog as in Fig. $1 \mathrm{~b}$ a few second later. The dog lies down and is only able to take a few crawling strides.

dogs a gradual decrement was found from the start of stimulation.

Stimulation at $3 \mathrm{~Hz}$ for $3 \mathrm{~s}$ after induced fatigue revealed a decrease in the fourth and fifth response to $40 \%$ returning to the former level during the next $4 \mathrm{~min}$. In some dogs the $15 \mathrm{~Hz}$ stimulation had to be repeated before a decrement appeared at $3 \mathrm{~Hz}$ stimulation (Fig. 2).

In some 12-14-week-old dogs in which the disease had just started, several trials of 15 $\mathrm{Hz}$ stimulation failed to reveal a decrement which was, however, present at a repeated trial few weeks later.

$3 \mathrm{~Hz}$ stimulation for $3 \mathrm{~s}$ in dogs with acquired MG did not reveal any abnormality. $50 \mathrm{~Hz}$ stimulation for $20 \mathrm{~s}$ followed by 3 $\mathrm{Hz}$ for $3 \mathrm{~s}$ provoked a significant decrement in 2 dogs. On exposure to $15 \mathrm{~Hz}$ stimulation for $5 \mathrm{~min}$ there was $\mathrm{s}$ gradual decrease in amplitude in all 5 dogs, followed by a sign- 

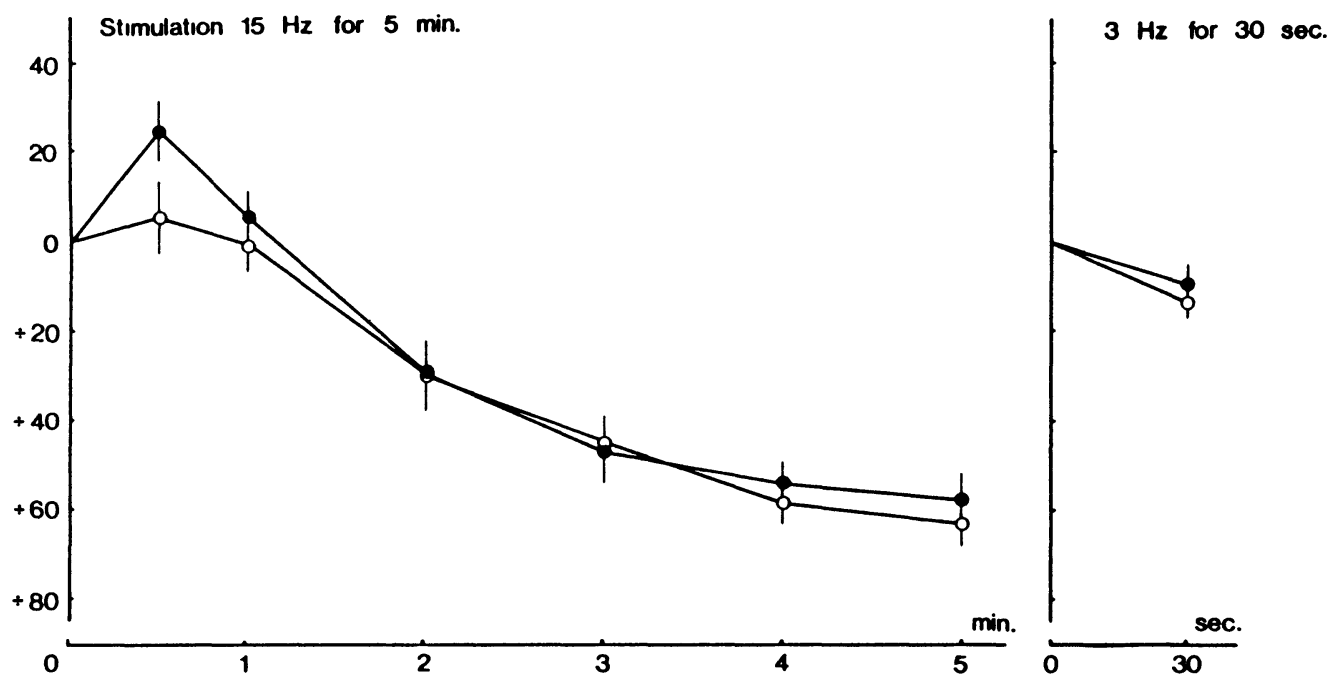

Figure 2. Congenital myasthenic syndrome. Electrophysiological findings in 14 cases. The average percentage change of the electrical response to $15 \mathrm{~Hz}$ stimulation, followed by $3 \mathrm{~Hz}$ for $3 \mathrm{~s}$. In 10 dogs 2 trains of $15 \mathrm{~Hz}$ stımulation were applied to induce a significant decrement at $3 \mathrm{~Hz}$ stımulation (1. e. more than $10 \%)$. The vertical bars indicate SEM.

- First train. $n=14$

$\multimap$ Second train. $n=10$

ificant decrement at $3 \mathrm{~Hz}$ stimulation for $3 \mathrm{~s}$ (Fig. 3). The action potential to single stimuli reached the original level in a few minutes. The decrement at $3 \mathrm{~Hz}$, however, persisted for $20 \mathrm{~min}$ or longer.

Effect of anticholınesterases on clinical signs and electrophysiological changes

Edrophonium or neostigmine administered intravenously during attacks of weakness had no clinical effect on the adult Gammel Dansk Hønsehund. However, given to 12-14 weeks ols dogs during the early period of the disease, before characteristic electrophysiologic changes had developed, intravenous injection of edrophonium or neostigmine had an immediate, but transient effect. The attacks were prevented for only 10-30 s after injection of edrophonium, even in do- ses of $2 \mathrm{mg}$ per $\mathrm{kg}$ body weight, but for 10-15 min after injection of neostigmine.

A similar dose of neostigmine injected into 2 dogs having acquired MG with generalized weakness had a dramatic effect. The dogs recovered muscular strength immediately and were able to walk and run. New attacks were not seen until several hours after an injection.

Prolonged oral neostigmine treatment of the Gammel Dansk Hønsehund did not abolish the attacks of muscle weakness or the amplitude decrement.

Daily oral treatment with neostigmine of dogs with acquired MG improved the condition. The dogs regained appetite and muscular strength. However, there was still impaired oesophageal function after a medication which ostensibly restored the limb 

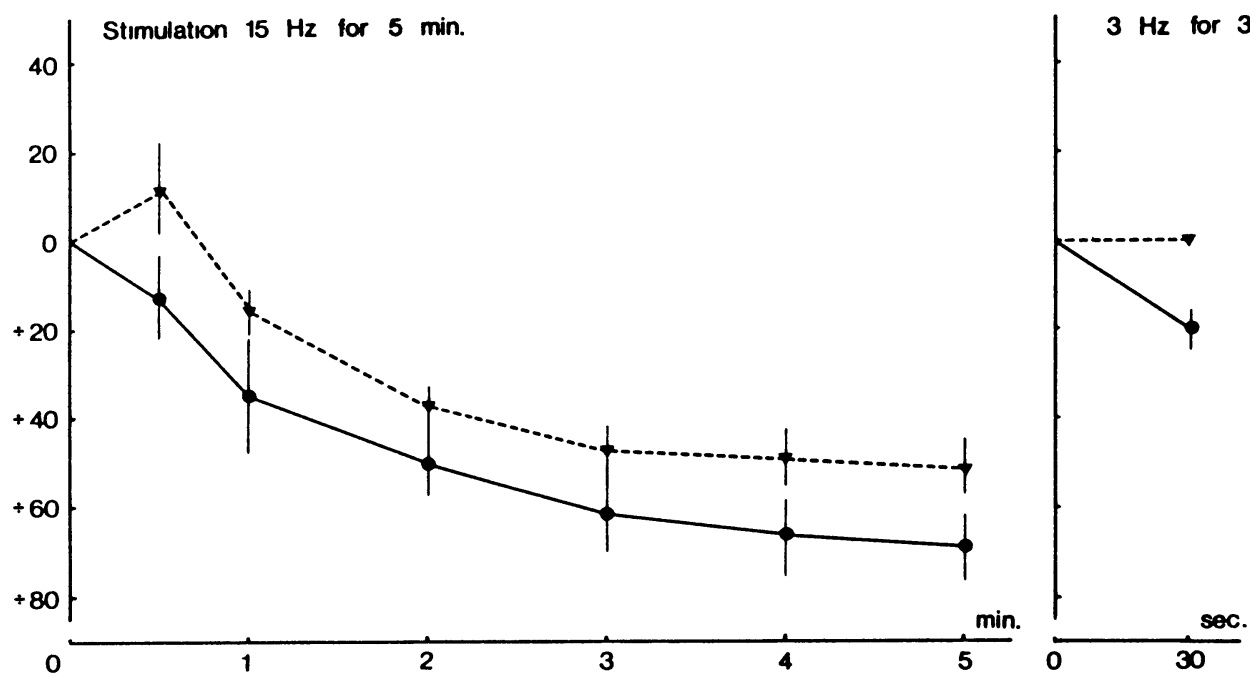

Figure 3. Acquired myasthenia gravis. Electrophysiological findings before and after injection of neostıgmıne. The average percentage change of the electrical response to $15 \mathrm{~Hz}$ stımulation and $3 \mathrm{~Hz}$ stimulation.

A gradual decrease in amplitude of about $70 \%$ after $15 \mathrm{~Hz}$ stımulation and a $20 \%$ decrement after $3 \mathrm{~Hz}$ stımulation. After intravenous administration of $0.1 \mathrm{mg}$ neostıgmine ( $2 \mathrm{dogs})$ and $0.5 \mathrm{mg}$ neostigmine (2 dogs) per $10 \mathrm{~kg}$ body weight the response to $3 \mathrm{~Hz}$ stımulation was normalized. The vertıcal bars indicate SEM.

$\longrightarrow$ Before adminıstratıon of neostigmine. $n=4$

r....... After administration of neostigmine. $n=4$

muscles (Table 1) as demonstrated by X-ray examination. Furthermore, oral treatment with neostigmine normalized the electrophysiologic abnormalities (Fig. 4).

The dogs (Gammel Dansk Hønsehund) tested in an ergometer (ergometer speed $129-152 \mathrm{~m} / \mathrm{s}$ ) showed evidence of fatigue 3-15 min after injection of neostigmine similar to the findings before its administration. The dog treated orally with neostigmine 3 times daily was able to run for 30 min before muscle fatique appeared, which was 10-15 min longer than before medication. Electrophysiological examination, however, did not reveal any improvement. Intravenous neostigmine or edrophonium before or during repetitive stimulation had no effect on the electrophysiological changes, regardless of the dosage (Figs. 5 and 6). In the 12-14-week-old dogs injection or edrophonium during a long $15 \mathrm{~Hz}$ train minimized the "electrical fatigue" from $60 \%$ to $12 \%$, but did not prevent the decrement induced by $3 \mathrm{~Hz}$ stimulation immediately after the $5 \mathrm{~min}$ stimulation. When the dogs were more than 6 months old, edrophonium had no effect on the electrical changes induced by $15 \mathrm{~Hz}$ stimulation.

In acquired $\mathrm{MG}$ intravenous neostigmine given during $15 \mathrm{~Hz}$ stimulation prevented the "electrical fatigue" and the myasthenic decrement at $3 \mathrm{~Hz}$ stimulation after induced fatigue (Fig. 3). 

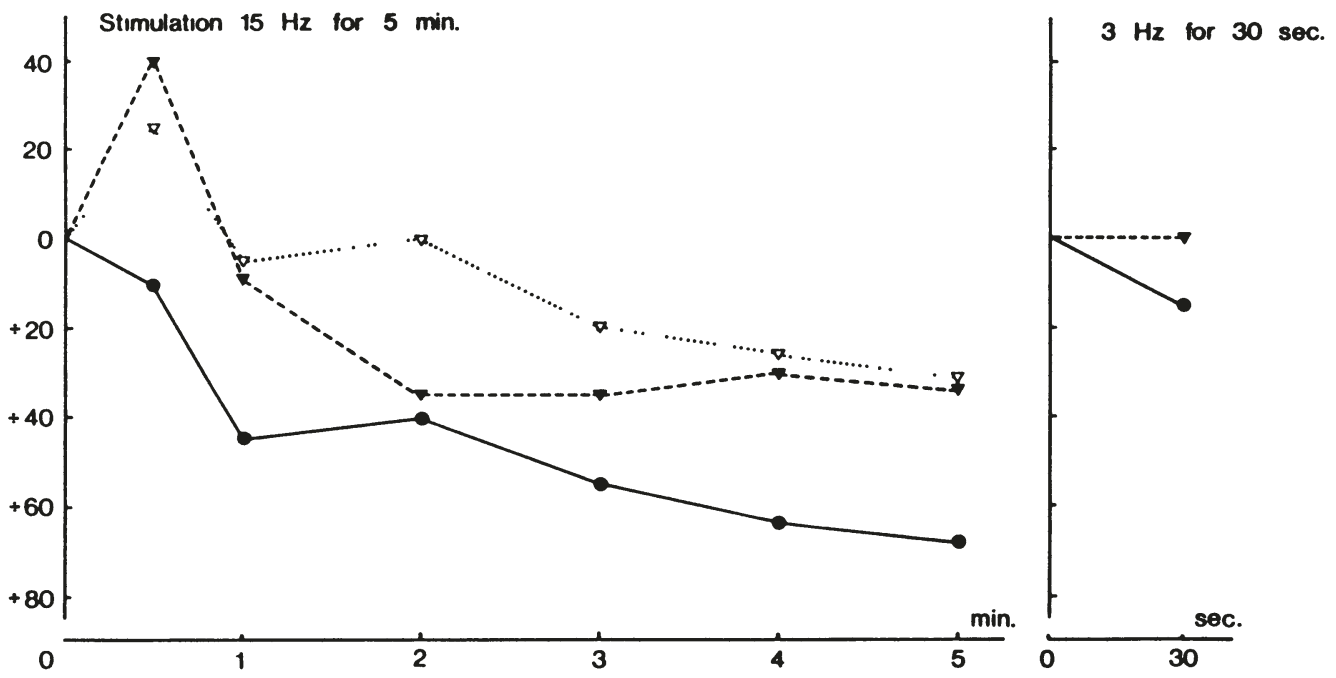

Figure 4. Acquired myasthenıa gravis. Electrophysıological findings before and after injection or oral treatment with neostigmine in 1 dog.

Trans of repetitive stimulation of $15 \mathrm{~Hz}$ for $5 \mathrm{~min}$ followed by $3 \mathrm{~Hz}$ for $3 \mathrm{~s}$. Treatment with neostigmine normalized the response to repetitive stımulation at $15 \mathrm{~Hz}$ and released the transmission block at $3 \mathrm{~Hz}$ stımulation.

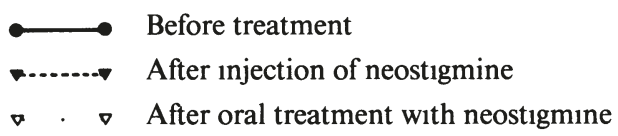

\section{Antıbodies to acetylcholine receptors}

The presence of antibodies to acetylcholine receptors in plasma from 8 dogs of the breed Gammel Dansk Hønsehund with the congenital myastenic syndrome and 4 dogs with acquired MG was determined, using both canine and human acetylcholine receptor preparations. As shown in Table 2, no antibodies were found in Gammel Dansk Hønsehund, whereas plasma from dogs with acquired MG contained antibodies to acetylcholine receptors from canine and human skeletal muscle.

\section{Discussion}

The clinical, electrophysiological, pharmacological and immunological features of the congenital myasthenic syndrome in the Gammel Dansk Hønsehund described here distinguish it from congenital MG in Jack Russel Terriers and Smooth Fox Terriers as well as from acquired MG. The most striking difference is the lack of response to anticholinesterases in the Gammel Dansk Hønsehund. Neither neostigmine nor edrophonium had any significant effect on the clinical or electrophysiological patterns in the fully developed disease.

Anticholinesterase drugs potentiate the action of acetylcholine by blocking acetylcholinesterase and are particularly effective in postjunctional transmission defects. The lack of effect of anticholinesterase in the congenital myasthenic syndrome indicates 

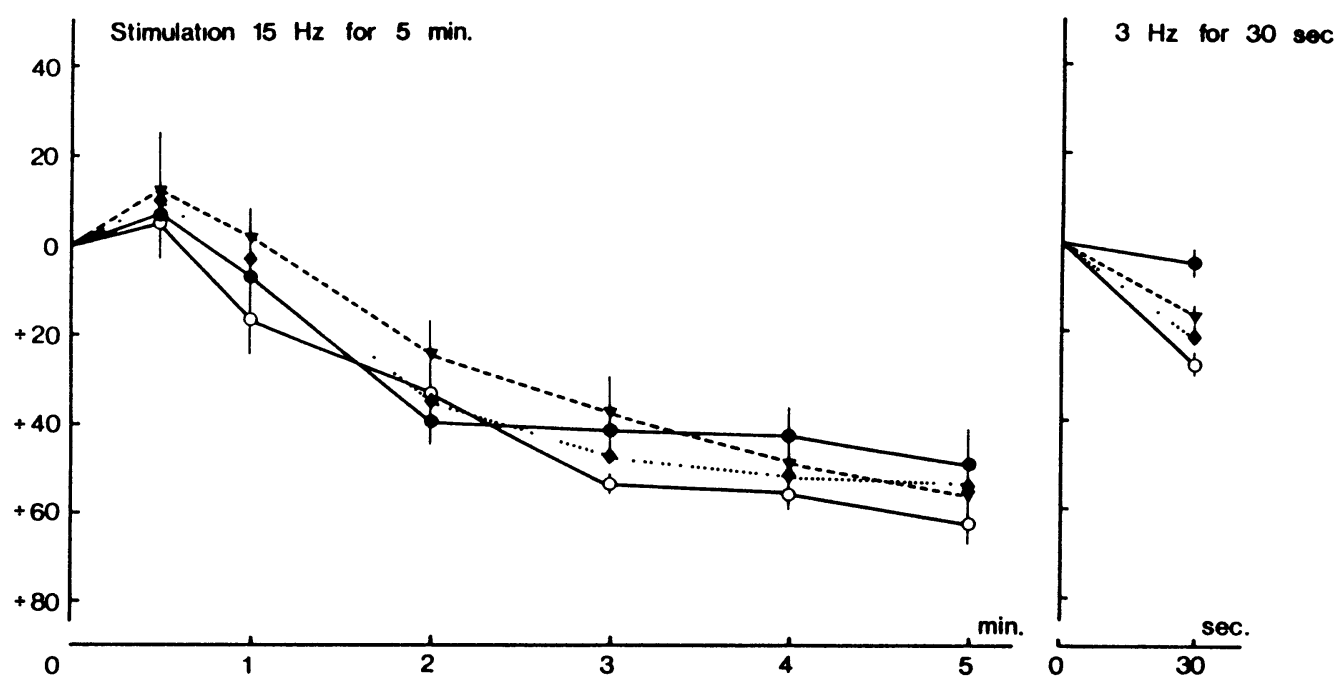

Figure 5. Congenital myasthenic syndrome. The average percentage change of the electrical response to $15 \mathrm{~Hz}$ stimulation followed by $3 \mathrm{~Hz}$ for $3 \mathrm{~s}$ before and after 1 . v. injection of $0.5 \mathrm{mg}$ neostigmine per $10 \mathrm{~kg}$ body weight. No significant electrophysiological change after injection of neostigmine at either type of stımulation. The vertical bars indicate SEM.

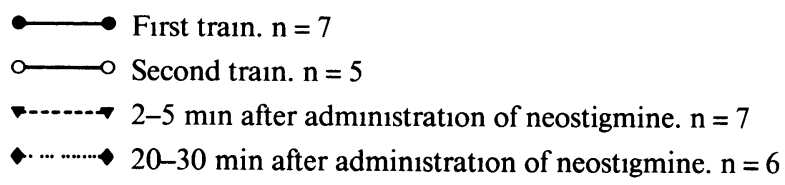

presynaptic involvement as the cause of the transmission defect. In young dogs anticholinesterase administered in the recommended dose (Palmer \& Barker 1974, Darke et al. 1975, Lorenz et al. 1972, Witt \& Ludwig 1978) initially abolished the myasthenic attack, but symptoms returned within a very short period. When the dogs grew older than 6 months, anticholinesterase had no clinical or electrophysiological effect.

In congenital MG in the Jack Russel Terrier, Springer Spaniel (Lennon et al. 1981), and Smooth Fox Terrier (Miller et al. 1983) an improvement of muscle strength after administration of anticholinesterase drugs has been reported. The response to anticholinesterase was used as a diagnostic test. The disease was in all 3 breeds relentlessly progressive from episodic attacks of weakness to generalized weakness and muscle wasting rendering the dogs unable to ambulate in spite of intensive treatment. Death usually occurred before 1 year of age. In contrast, the disease in Gammel Dansk Hønsehund is non-progressive.

In acquired MG, administration of anticholinesterase immediately abolished the electrical decrement and normalized the response to a long train of $15 \mathrm{~Hz}$ stimulation. In contrast, in the young Gammel Dansk Hønsehund anticholinesterase did not prevent the decrement at $3 \mathrm{~Hz}$, but minimized the decrease at $15 \mathrm{~Hz}$ stimulation. This probably reflects a less severe presynaptic invol- 

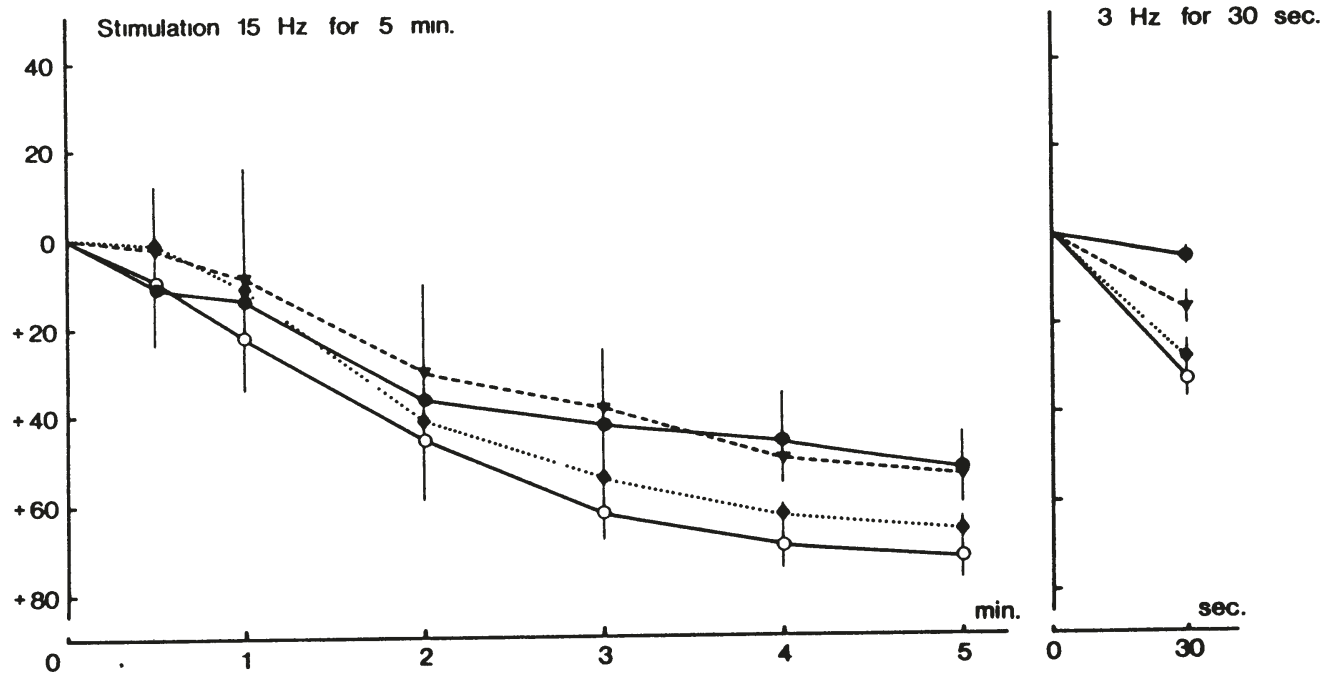

Figure 6. Congenital myasthenic syndrome. The average percentage change of the electrical response to $15 \mathrm{~Hz}$ stımulation followed by $3 \mathrm{~Hz}$ for $3 \mathrm{~s}$ before and after 1 . v. injection of $1 \mathrm{mg}(1 \mathrm{dog})$ and $2.5 \mathrm{mg}(3$ dogs) neostigmine per $10 \mathrm{~kg}$ body weight. Neostigmine in higher doses did not change the decrement. The vertical bars indicate SEM.

$\longrightarrow$ First train. $n=4$

$\multimap$ Second train. $n=4$

-..-.- 2-5 min after administration of a high-dose of neostigmine. $n=4$

- . $•$ 20-30 min after administration of a high-dose of neostıgmine. $n=4$

vement in the young animal with a higher ability to restore acetylcholine and is compatible with the fact that sometimes it was necessary to repeat the fast rate stimulation before a decrement appeared following $3 \mathrm{~Hz}$ stimulation. In acquired MG $3 \mathrm{~Hz}$ stimulation revealed a decrement when given after tetanic stimulation as described in the Smooth Fox Terriers (Miller et al. 1983).

A decrease during $15 \mathrm{~Hz}$ stimulation does not in itself indicate the presence of a myasthenic syndrome in Gammel Dansk Hønsehund, as a similar decrease was found in some control dogs and also in obligatory heterozygous carriers which were clinically normal (Flagstad \& Trojaborg 1983).

The initial amplitude increase during $15 \mathrm{~Hz}$ stimulation found in the myasthenic syndrome was not present in any of the dogs with acquired MG. It has, however, been described in human MG (Brown \& Johns 1969, Mayer \& Williams 1974) in which it has been attributed to a presynaptic defect.

The observation that antibodies to acetylcholine receptors are not demonstrable in Gammel Dansk Hønsehund with the congenital myasthenic syndrome is in agreement with reports that receptor antibodies are not found in human patients with congenital MG or the Lambert-Eaton syndrome (Engel et al. 1981, Vincent et al. 1981).

The congenital MG syndrome in dog and man are clinically and biochemically different from the acquired MG in dog and man 
Table 2. Antıbodies to acetylcholine receptors in the Congenital Myasthenic Syndrome of Gammel Dansk Hønsehund and in acquired Myasthenia gravis in other dogs.

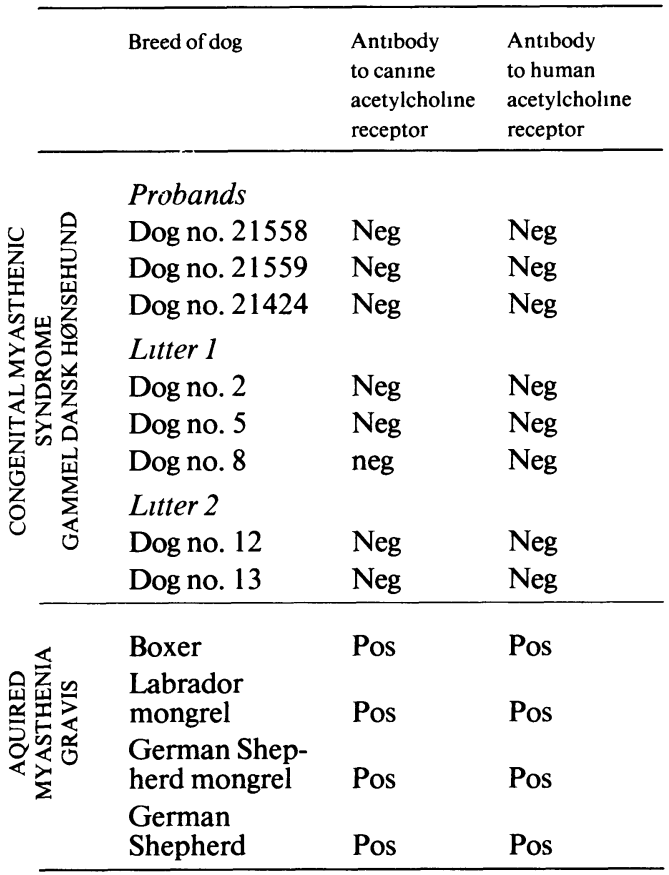

$\mathrm{Neg}=$ negative $; \mathrm{Pos}=$ positive

in which antibodies to acetylcholine receptors are present (Lennon et al. 1978, Vincent 1980). The latter result from IgG blockade of acetylcholine receptors and complementmediated destruction of skeletal muscle (Vincent 1980, Rødgaard et al. 1987). Congenital MG syndromes may arise from presynaptic or postsynaptic defects (Vincent 1980). Owing to the absence of detectable antibodies to acetylcholine receptors and the lack of response to anticholinesterases, the congenital myasthenic syndrome in Gammel Dansk Hønsehund most closely resembles the human congenital MG syndrome and may be due to a defect in the synthesis of acetylcholine, impaired release of acetylcho- line, abnormality of acetylcholine-induced ion channels, or deficiency of end-plate acetylcholinesterase (Engel et al. 1981, Vincent et al. 1981).

\section{Acknowledgements}

This investigation was aided by grants from the Danısh Agricultural and Veterinary Research Council (13-3259) and from the Leo Research Foundation.

The Neuromatic 2000 was granted by the Simon Spres Foundation.

\section{References}

Bellah JR, Sttft ME, Russel RG. Thymona in the dog: Two case reports and review of 20 add1tional cases. J. Amer. vet. med. Assoc, 1983, 183, 306-331.

Brown JC, Johns RJ Clinical and physiological studies of the effect of guanidine on patients with myasthenia gravis. Johns Hopkıns Med. J. 1969, 124, 1-8.

Darke $P G G$, McCullagh KG, Geldart $P H$ Myasthenia gravis, thymona and myositis in a dog. Vet. Rec. 1975, 97, 392-394.

Engel AG, Lambert EH, Mulder DM, Gomez $M R$, Whitaker JN, Hart Z, Sahaskı K Recently recognized congenital myasthenic syndromes: (a) end-plate acetylcholine (ACh) esterase deficience (b) putative abnormality of the ACh induced ion channel (c) putative defect of ACh resynthesis or mobilizationclinical features, ultrastructure and cytochemistry. Ann. NY Acad Sci. 1981, 377, 614-639.

Flagstad $A^{\cdot}$ A new hereditary neuromuscular disease in the dog breed Gammel Dansk Hønsehund. Genetic investigations. Hereditas 1982, 96, 211-213.

Flagstad A, Trojaborg $W$ Hereditary neuromuscular disease in the dog breed Gammel Dansk Hønsehund. Electrophysiological findings and genetic aspects. Proceedings from Voorjaarsdagen, Amsterdam, 1983, 109-114. 
Flagstad A, Nielsen P, Trojaborg $W$ Pharmacokınetıcs and pharmacodynamics of guanıdıne hydrochloride in an hereditary myasthenı gravis like disorder in dogs. J. vet. Pharmacol. Therap. 1986, 9, 318-324.

Hall GA, Howell JMcC, Lewls DG Thymona with myasthenia gravis in a dog. J. Path. 1972, 188, 177-180.

Jenkıns WL, Van Dyk E, McDonald CB Myasthenia gravis in Foxterrier litter. J. South Afr. vet. Assoc. 1976, 47, 59-62.

Johnson RP, Watson ADJ, Smith J, Cooper BJ Myasthenıa in Springer Spaniel littermates. J. Small Anim. Pract. 1975, 16, 641-647.

Karmenskaya MA, Elmquist D, Thesleff $S \mathrm{Gu}-$ anidine and neuromusular transmission. 1 . Effect on transmitter release occurring spontaneously and in response to single nerve st1muli. Arch. Neurol. 1975a 32, 505-509.

Kelly MJ Myasthenia gravis - A receptor disease. Comp. Cont. Ed. 1981, 3, 544-555.

Lennon $V A$, Palmer $A C$, Pflugfelder CM, Indrierl $R J$ Myasthenıa gravis in dogs: Acetylcholıne receptor deficiency with and without antireceptor autoantibodies. Genetic control of autoimmune disease. New York, Elsevier, North Holland Biomedical Press 1978, 1, 295-305.

Lennon VA, Lambert EH, Palmer AC, Cunningham JG, Christie TR Acquired and congenital myasthenıa gravis in dogs - a study of 20 cases. in Satoyosh $E$ Myasthenıa gravis - pathogenesis and treatment. Tokyo, Unıversity of Tokyo Press 1981, 41-54.

Lorenz MD, DeLahunta A, Alstrom DH Neostigmine-responsive weakness in the dog, sim1lar to myasthenia gravis. J. Amer. vet. med. Assoc. 1972, 161, 795-802.

Mayer RF, Williams IR Incrementing responses in myasthenia gravis. Arch. Neurol. 1974, 31, 24-26.

Miller LM, Lennon VA, Lambert EH, Reed SM, Hegreberg GA, Miller JB, Ott RL Congenital myasthenia gravis in 13 Smooth Fox Terrier. J. Amer. vet. med. Assoc. 1983, 182, 694-697.

Miller LM, Hegreberg GA, Prieur DJ, Hamilton $M J$ Inheritance of congenital myasthenia gravis in Smooth Fox Terrier dogs. J. Hered. 1984, 75, 163-166.
Nielsen FC, Rødgaard A, Djurup $R$, Somnier $F$, Gammeltoft $S$ A triple antıbody assay for quantitation of plasma IgG subclass antibodies to acetylcholine receptors in patients with myasthenia gravis. J. Immunol. Methods 1985 , $83,249$.

Otsuka $M$, Endo $M$ The effect of guanidine on neuromuscular transmission. J. Pharmacol. Exper. Therap. 1960, 128, 273-282.

Palmer AC, Barker $J$ Myasthenia in the dogs. Vet. Rec. 1974, 95, 452-454.

Palmer AC, Goodyear JV Congenital myasthenıa in the Jack Russel Terrier. Vet. Rec. 1978, $103,433-434$.

Palmer $A C$ Myasthenia gravis. Vet. Clın. North Amer.: Small Anım. Pract. 1980, 1, 213-222.

Pflugfelder CM, Cardinet GM, Lutz H, Hollıday $T A$, Hansen $R J$ Acquired canıne myasthenı gravis. Immunocytochemical localization of immune complexes at neuromuscular junctions. Muscle \& Nerve, 1980, 4, 289-295.

Poffenbarger E, Klausner JS, Caywood DD Acquired myasthenia gravis in a dog with thymona: A case report. J. Amer. Anim. Hosp. Assoc. 1984, 21, 119-124.

Rødgaard A, Nielsen FC, Djurup $R$, Somnier $F$, Gammeltoft $S$ Acetylcholıne receptor antibody in myasthenia gravis: predominance of IgG subclasses 1 and 3. Clin. exp. Immunol. 1987, 67, 82-88.

Trojaborg $W$, Flagstad A A hereditary neuromuscular disorder in dogs. Muscle \& Nerve 1982, 5, 30-38.

Vincent $A$ Immunology of acetylcholine receptors in relation to Myasthenia gravis. Physiol. Rev. 1980, 60, 756-824.

Vincent A, Cull-Candy SG, Newsom-Davis J, Trautman A, Molenaar PE, Polak $R L$ Congenital myasthenı: end-plate acetylcholine receptors and electrophysiology in five cases. Muscle \& Nerve 1981, 4, 306-318.

Wallace $M E$, Palmer $A C$. Recessive mode of inheritance in myasthenıa gravis in the Jack Russel Terrier. Vet. Rec. 1984, 114, 350.

Witt VM, Ludvig RD Anticholinesterase - responsive weakness in the canıne similar to myasthenia of man. J. Amer. Anım. Hosp. Assoc. $1978,14,138-142$. 
Zacks SI, Shields DR, Steinberg SA A myasthenic syndrome in the dog. A case report with electron microscopic observations on motor endplates and comparison with the fine structure of end plate in myasthenia gravis. Ann. Ny Acad. Sc1. 1966, 135, 79-97.

\section{Sammendrag}

Kongenitalt myastenisk syndrom hos Gammel Dansk Honsehund

Kongenitalt myastenısk syndrom hos racen Gammel Dansk hønsehund sammenlıgnes klınısk, elektrofysiologisk, farmakologisk og immunologisk med erhvervet myasthenia gravis hos hund. Antıkolınesterase behandlıng har ingen terapeutısk eller elektrofysiologısk effekt på det kongenıtale myasthenıske syndrom. Den manglende effekt af antikolinesterase indicerer en presynaptisk defekt 1 modsætning til forholdene ved myasthenia gravis, hvor det neuromuskulære blok skyldes en postsynaptısk defekt.

Det myasthenıske syndrom hos Gammel Dansk Hønsehund kan klassificeres i gruppen af kongen1tale myastheniske sygdomme hos hund og mennesker, baseret på manglende antistofdannelse mod acetylcholınreceptor 1 den motoriske endeplade.

(Recelved May 20, 1988, accepted June 29, 1988)

Reprints may be requested from: A. Flagstad, Department of Small Anımal Diseases and Clınical Practice, Royal Veterinary and Agricultural Unıversity, 13 Bülowsvej, DK-1870 Frederıksberg C, Denmark. 